\title{
The Child in the Family Turmoil
}

\author{
Didier Grandgeorge* \\ Homeopath Pediatrician, FREJUS, France
}

Submission: February 01, 2018; Published: February 09, 2018

*Corresponding author: Didier Grandgeorge, Homeopath Pediatrician, FREJUS, France, Email: drgrandgeorge@hotmail.com

\section{Perspective}

We live in a post-industrial society in search for a future, where all the classical values have been put into question: a kind of "every man for himself" gives the full right to the forces of the ego and the family, that used to be the basic unit of our social framework, is now shaken in every part into the general turmoil. What would the child become caught into this eminently LUETIC frame?

We must admit that he has a surprising ability to adapt and most of the times things go well at the end. But sometimes it will be harder and it is then that our small pills would do wonder to help restore the threatened balance.

We will see successively interesting remedies in case of grief, divorces, birth in family, relocation, sexual abuses, wars, bankruptcy, absent father, adoption, and homosexual parental couple.

\section{The child confronted with the morning}

\section{IGNATIA AMARA 15C to 30C}

This is the first remedy to give to the whole family in case of grief/ bereavement: sighing, weeping alternating with laughter, sensation of a lump either in the throat or in the solar plexus : escalating doses should be given ( for example one dose a week starting with 15C, then 18C, then 24C, then 30C).

\section{ARSENICUM ALBUM 15C to 30C}

The child becomes fastidious, obsessional, collector and sleppless (wakes up around $1 \mathrm{am}$ ). He dresses in black, draws skeletal, doesn't want to grow up because when you grow up you get older and then you die!

Give one dose every fifteen days in escalating dilution like with IGNATIA.

\section{ARNICA 15C to 30C}

Appropriate in case of a sudden death which can be very damaging: a loved one dies in a car accident or kill himself. ARNICA treats the bruise of the body and the bruise of the soul too. In case of death due to an accident it will be followed by
SULFURICUM ACIDUM 15C or 30C (fear of accident, rush that could lead to future accident: the story repeats itself!!!!).

\section{CALCAREA SILICICA: 15C to 30C}

This is the right remedy when the child keeps in touch with the dead: at night he can see them, talk to them, what often trigger night terrors and insomnias. "There are noises, shadows, ghosts...."

\section{URTICA URENS 15C to 30C: the death of the father}

The close relationship with the mother is lost thanks to the father. If the father dies prematurely, this process can't be achieved. The bond between the mother and the child is too strong and the child suffers from serous otitis, asthma, hives.... and later in time rheumatisms and allergies to shellfish.

\section{MURIATICUM ACIDUM 15 to 30C: the death of the mother}

Hahnemann is the one who mentions in his pathogenesis of MURIATICUM ACIDUM a restless sleep, with terrifying dreams "the fourth day", "I dreamt that my mother was dying ". This is a remedy in case of hemorrhoids in children and severe gastro esophageal reflux with faintness. In almost every case the child will complain about acid reflux.

\section{HURA BRASILIENSIS: the death of the child}

In our society the child had never had so little risk of dying from a disease but remains the accidental death during puberty due to risky behaviors. Nevertheless the fantasy of the death of a child is omnipresent and daily exploited to sell more and more expensive vaccines: an armada of medical representatives is constantly harassing the doctors with their techniques derivate from the Neuro-Linguistic programming." Responsibility, reproach, miss something, meningitis, vaccination": here are the main key words used with our poor physicians who during their long studies didn't get to learn about the psychological or philosophical approach; in two words it is either death or vaccine and the message is passed on to the parents the same way and the latter have no other choice than to accept the life 
saver vaccine. The revenues of this industry are countable in billions of euros what increase our social deficits and lead to numerous delocalization. ... Those anxious parents will come to their sense thanks to this remedy that will solve numerous of rheumatism troubles.

\section{The child confronted with the divorce of his parents}

\section{IGNATIA AMARA: There is no more love (15C to $30 \mathrm{C}$ )}

Like after a death, this is the chosen remedy in acute when the parents get separated: the child loses sleep, somatizes with a constant cough or with stomach ache, he is constantly sighing, goes easily from laughing to crying, complains about a lump in the throat....

\section{PHOSPHORICUM ACIDUM 15C to 30C: A huge loss of energy}

Suddenly the child feels very tired, wants to sleep all the time, loses his hair, suffers from chronic diarrhea, and loses weight. We can notice stained nails, greasy and thin hair, and intolerance to orange juice.....

\section{LACHESIS MUTUS 15C to 30C: Jealousy}

The child is alone with a depressed parent who will take him in his own bed to sleep: all the conditions are met for the Oedipus complex. The same if there is a sudden arriving of a child of the same age that will create an intolerable competition: he becomes restless, loquacious and can't stay focus, catch affections on the left side of the body, evolving to the right side. Furthermore he becomes very sensitive to insects bites and brings back lice from school.

\section{NATRUM CARBONICUM 15C to 30C: the search of the lost harmony}

The child dreams to see the lost harmony in the family being restored. Hypersensitive he indulges himself with music, especially piano. He runs away from the sun, gets white stains on the face, suffers from encopresis, and turns his ankles. A key symptom: he refuses to eat honey what is the symbol of the perfect harmony experienced during the honey moon period.

\section{BAPTISIA 7C to30C: reconstitution of the family jigsaw}

Suddenly the child starts having painless angina, what is typical from this remedy. The family is broken into pieces and he dreams to pick up the pieces and put things together again.

\section{SYMPHYTUM 15C to 30C: to re-solder the parental couple}

Quite often a divorce creates some fractures, a family fracture: SYMPHYTUM, the comfrey root, will re-solder the bones and the couple (to give to each parent) if it is not too late....the holy spirit becomes a man: it is necessary to have a foot into the third dimension of love to be able to stay still in the very unstable second dimension: it used to be the meaning of the religious engagement in the traditional marriages but it is very rare nowadays....

\section{ANACARDIUM ORIENTAL: The choice 15C to 30C}

The child is torn apart between the two families: on both side he is under any kind of psychological pressure to make him deny the other one who is denigrated. Quite often it is a case of share custody with residence alternating. The child is faced with a great indecision, becomes nasty, cruel with animals and suffers from multiple somatizations for which we hesitate: allopathic medicine, homeopathy treatment or both.... The worth case scenario would be that one part is rejected and it ends up in a parental alienation.....

\section{COCCUS CACTI: to get rid of the stranger}

This remedy is well known to eject the foreign bodies, cinders in the eye. The child will develop a whooping cough with a great accumulation of sticky mucus that he vomits. The foreign body to eject is the new friend of the mother or the little brother imposed on him...

\section{The child confronted with births in family}

The jealousy is the predominant feeling because the new born baby gets all the attention of the mother and is the center of all the care especially when the oldest child used to be a lonely child and therefore "the center of the world" of the family.

\section{LACHESIS MUTUS 15C to $30 \mathrm{C}$ or even 1M, 10M : OEDIPE, when you hold us...}

The dictatorial child expresses his jealousy with a continuous flood of words, some somatizations on the left side of the body, or shifting from the left side to the right side. Lice are a good marker of this remedy: lice have to be killed (the lice are said "les poux" in French what sounds like "l'époux", meaning the husband); the husband meaning the father. We are in the heart of the Oedipus complex. To be noticed a touch of hemorrhage, for example a left sided epistaxis.

\section{HYOSCYAMUS NIGER: the jealous exhibitionist; 15C to $30 \mathrm{C}$ or even $1 \mathrm{M}$ or $10 \mathrm{M}$}

The child is not dictatorial as with LACHESIS but he catches any opportunities to get himself totally naked and wanders like that in front of everybody. He is faced with all kind of fears and adopts a baby behavior with silly fits of laughter.

\section{PULSATILLA: never leaves the mother; $15 \mathrm{C}$ to $30 \mathrm{C}$ or even $1 \mathrm{M}$ or $10 \mathrm{M}$}

The arriving of a little sister or a little brother is experienced as a true betrayal what will induce a depression that can be severe: I saw a young girl firing a bullet in her own head and after a miraculous surgery she ended up in a psychiatric ward where she had a totally regressive behavior. But she improved in a spectacular way after being given some doses of PULSATILLA; the child sucks his tomb and covers himself with teddy bears to sleep.... 
VERATRUM ALBUM: the one who lies is a dreamer! (In French a lie is said mensonge what sounds like ment (he lies) and songe (dreams) combined together) $15 \mathrm{C}$ to $30 \mathrm{C}$ or even $1 \mathrm{M}, 10 \mathrm{M}$

The arriving of a second child is experienced as a fall from the pedestal and the child takes refuge in an imaginary world full of princesses and princes. He fantasizes, tells the neighbors that his parents beats him up! At a physical level, he will experience severe diarrhea with dehydration what will require an hospitalization to put the child on the drip/ infusion: in French infusion can sounds like father fusion/ fusion with the father (per sounds like père what means father and fusion), then the fusion with the father will allow the child to escape the exclusive relationship with the mother.

\section{The relocation}

The first relocation in life is the birth and the last one is the death: every move will reawake the anxiety related to the experience of those two compulsory passages!

\section{IGNATIA AMARA: the loss of love}

The child changes area and will not be able to see his school friends anymore. The child might have an angina the first day at school: the throat is painful, but, paradoxically, he is able to eat hard bred but can't swallow the bowl of milk!

\section{CAPSICUM: nostalgia for a lost paradise}

The child takes refuge in food; it is the regression to the oral stage and obesity: it can be noticed thanks to his red cheeks without fever and his tendency to otitis......

\section{MEZEREUM: the loss of reference}

The child is disorientated: all his usual references have disappeared. Consequently he suffers from bilateral maxillary sinusitis: he snores at night, he dribbles saliva with an open mouth, complains about stomach ache and teeth are covered with tartar: two doses of MEZEREUM in 15C in an interval of two days will do wonder.

\section{PHOSPHORICUM ACIDUM: the exhausting deep sorrow}

The child loses weight, loses his hair, wants to sleep all the time, has white spots on the nails and can't drink his orange juice any more at breakfast.

\section{NITRICUM ACIDUM: it is unforgivable!}

The relocation has been experienced as an unforgivable affront; the child is constantly in a bad mood and remains silent. He is noticeable thanks to his verruca and his taste for the piece of fat he grabs from his neighbor's plates!

\section{CLEMATIS ERECTA: unjustly accused arrested and deported}

We can think about the DREYFUS affair, about the several deportations that happened during the last war and that have haunted the family history. The child is sickly and suffers from skin troubles such as ringworm and various neuralgias that will get worst at full moon.

\section{The child faced with sexual abuses}

Since FREUD we know that there is an infantile sexuality especially at the phallic stage when the child exhibits his sex and the Oedipus complex when he tries to get the attention of an adult by adopting some behaviors that can be a bit lascivious at time: but it doesn't diminish the responsibility of the depraved adults who will commit the irreparable by bringing the child into their immature and perverse sexual fantasies. To restore the balance of a pedophile we described somewhere else the remedy VERBASCUM THAPSUS.

\section{CRESOLUM: Rape before puberty}

This is not a very well-known remedy that does wonder with people who experienced a rape during their childhood, before the puberty. After few doses they will be healthy again and are serene. I think for example about the observation of a mother suffering from various unexplained fainting who brought me one day a health book she has just found again hidden inside a cupboard : at the fourth month examination the GP wrote in a not very legible way "very dilated anal orifice". With few doses of CRESOLUM 15C to 30C she was able to find again a good general balance.

\section{KREOSOTUM: Rape after puberty}

The episode can have been completely buried in the depth of the unconscious so much that only some somatic troubles remain such as white corrosive discharges, or even a vaginal cancer. A mother suffering from various troubles ask me some advices so I sent her to one of my GP colleague who will hesitate between SEPIA and KREOSOTUM. At the end he will chose KREOSOTUM one dose in 15C: few days after taking the remedy she reads again my book "homeopathy a path of life" and sees that this remedy can be in relation to rapes: suddenly she sees the scene when her uncle rapes her and understands her troubles and the discomfort she feels during the family reunion when this person is present .....

\section{The child and the war}

War is the most awful things the man has never invented and unfortunately he never gets tired of it. There are murders, rapes, wounds, the din of the bombs and the prisoners (CARCINOSINUM)... all this leaves marks that will be passed on to the future generations.

GERMANIUM METALLICUM: the war atmosphere.

A young girl who has been suffering from asthma since childhood had shingles at the age of three (shingles in French is said zona and a - zone means without any territory). I asked her what she wants to do next year, after the baccalaureat: "I want to study medicine! Where in Marseille? No in TEL AVIV I am a Jew and I wish to go to Israel to study medicine after my 
military service. I like the idea of fighting for my country “. Then I decided to give her few pills of GERMANIUM METALLICUM in 200C. Three days after she rang me: the shingles are out on my chest: after what the respiratory state will get stabilized and she will stay in Marseille for her studies....

The shingles is an excellent point of call for GERMANIUM METALLICUM which pathogenesis was realized by JEREMY SHERR in ENGLAND.

ACONITUM NAPELLUS: «I was just a little kid in a universe of dead »

It is what tells us Jerome whose family was killed by a bombing. Precocious, brilliant, he seems to be in a hurry and very agitated the mind always on alert: "I think about death every day and I can tell you that it is at $11 \mathrm{am}$ ".

ARSENICUM ALBUM: « you are dust and to dust you shall return»

He thinks that there is nothing after death and becomes agitated, meticulous, obsessed. He suffers from asthma: the thermal treatment in la BOURBOULE will do wonder (it is a sulfated water containing arsenic)

IGNATIA: to deal with the disappearance of the loved one.

Life becomes a valley of tears after all the misfortunes experienced during wars.

The child confronted with the bankruptcy of his parents

Our time is unfortunately prone to economical failures, unemployment, bankruptcy... it is the stress about challenging end of month, the over indebtedness, bank banned and the bailiffs. The child lives story of expulsions, shame and social regression.

\section{BRYONIA: the uprooted}

Further to the fear of poverty (AMBRA GRISEA, BRYONIA, CALCAREA CARBONICA, CALCAREA FLUORICA, CALCAREA SILICICA, CHLORUM, KALIUM CARBONICUM, MELILOTUS, NUX VOMICA,

PSORINUM, PULSATILLA, SEPIA, SULFUR) there is also the anxiety of being uprooted: one has to leave a familiar environment to go and live in a smaller place in a high crime area. Therefore the child will have pneumonia with pleural reaction ...

\section{BARYTA CARBONICA: the shame}

The child is ashamed of his own situation of degradation what will make him hide and keep a low profile. The mathematic brain stops working and the scores plummet, everything is confused: as could say MICHEL ZALA « the man who is down is laughed at». The child has large tonsils, snores and has sleep apnea (OPIUM).

\section{VERATRUM ALBUM: the lie}

He will make things up to hide the reality of the situation even if he suffers from severe diarrhea as mentioned above.

\section{NITRICUM ACIDUM: an unforgivable situation}

The degradation is due to the wrongdoing of others: it is unforgivable and the life will be lived rigidly and unhappily even if it is at the cost of suffering for example from cholesteatoma.

\section{COLCHICUM: the old and ruined nobility}

Despites a severe ruin one wants to keep the stylish collar: one of the big somatization at the teenage stage is the Sacrococcygeal cysts that will constraint the poor girl to show off her bottom for weeks at the hospital....

\section{The absent father}

The father can be absent either physically or morally, absorbed by his fight to earn money for the family life.

\section{NATRUM MURIATICUM: the father who doesn't communicate well}

The child himself will start talking very late and will stay secret: no one knows what is going on at school for example. He will have asthma every evening at 10 O'clock and will gorge with bread and salt, unless he is gluten intolerant.

\section{COPAIIVA: the child with no father}

A patient told me: «I am from an unknown father and a too well known mother ». My father disappeared when my mother was pregnant and we never heard of him again. The child will suffer from any kind of troubles such as chronic mucus of the respiratory ways for example or mucus in the bladder and hives.

\section{ASARUM EUROPEANUM: born from a European chance}

The child suffers from hypersensitivity to small noises what symbolized the rumor: his father is not his biological father: there is some doubts, the mother used to be with another man before and at the time of their encounter.

Sometimes and it is very common nowadays, the child is from a gamete donors that were implanted in BARCELONA.... And he suffers from chronic insomnia for example.

\section{The homosexual parents}

This is a more and more common situation: to my opinion it goes quite well as one of the two partner plays naturally a feminine role and the other one the masculine polarity. Said that we must see what those children will become in the long term; but we can have a fair idea as after the big world wars where thousands of men were killed, a lot of children for example were brought up in an exclusively feminine environment and they did adjust.

\section{The adoption}

The biggest stress experienced by the child is the moment when the mother decides to abandon him and get emotionally detached: KENT is the one who discovered MAGNESIA 
CARBONICA, (15C to 30C or even 1M, 10M) marvelous remedy to stabilize an adopted child with the help of few doses of PSORINUM 30C.

"I was the medical representative of an institute for abandoned children: a great number of them were dying until I discovered the remedy MAGNESIA CARBONICA" KENT MATERIA MEDICA.

\section{Conclusion}

Being a child in 2012 is not always easy, the society is changing and there is a need to adapt to all kind of situation that used to be rare and are becoming nowadays more and more common. The standard quiet family with a mother a father and the children living together on the same roof has become a minority. Luckily the plasticity of the child and his huge resilience capacity and the help of homeopathy will allow him not to become depressed or to suffer from complex somatizations.

A big thank to HAHNEMANN to have brought us this great manna!!!

Your next submission with Juniper Publishers
will reach you the below assets
- Quality Editorial service
- Swift Peer Review
- Reprints availability
- E-prints Service
- Manuscript Podcast for convenient understanding
- Global attainment for your research
- Manuscript accessibility in different formats
( Pdf, E-pub, Full Text, Audio)
- Unceasing customer service
Track the below URL for one-step submission
https://juniperpublishers.com/online-submission.php

